\title{
Evaluation of Introduced Pepper Accessions for Agronomic Characteristics in Summer-Autumn Season 2014 at Thua Thien Hue
}

\author{
Thao Thu Phan ${ }^{1}$, Hai Thi Hong Truong ${ }^{1,2}$ and Tho Huu Nguyen ${ }^{2}$ \\ 1. Hue University, 3 Le Loi Street, Hue City 47000, Vietnam \\ 2. Agronomy Faculty, College of Agriculture and Forestry, Hue University, 102 Phung Hung Street, Hue City 47000, Vietnam
}

\begin{abstract}
Five lines of introduced pepper obtained from National Institute of Horticultural and Herbal Science, Korea, namely YT1, YT2, YT3, YT4, KR1, and two local varieties, namely Chia Voi and Moi, were used in this study to evaluate bio-agronomy characteristics and yield components in summer-autumn season 2014 at Thua Thien Hue, Vietnam. The experiment was laid out in a random complete block design (RCBD) with three replications. The results showed that all of the introduced pepper accessions can grow under Thua Thien Hue condition. The introduced accessions as KR1, YT2 and YT4 showed good adaptability. These pepper lines had high yield and good fruit qualities, like Chia Voi. YT4 gave high number of leaves and plant height. Accession KR1 had the highest number of fruits per plant and yield (1,397.8 kg/ha). Accession YT2 had high fruit setting rate and the biggest fruit (8.08 g). YT2 and YT4 had high yield, which were equivalent to Chia Voi. These accessions need to be conducted another trials in different areas and seasons to confirm their growth ability and can be used in crop structure at Thua Hien Hue province and breeding programs.
\end{abstract}

Key words: Pepper, Capsicum sp., solanaceae, Thua Thien Hue.

\section{Introduction}

Pepper (Capsicum sp.) belongs to the genus Capsicum, members of the Solanaceae family, and is the second most importance vegetable crop after tomato. It originated from Peru and Bolivia [1], and is one of popular spicy vegetable throughout the world. Pepper fruit is considered as rich nutrients source, in $100 \mathrm{~g}$ of fresh pepper containing $3.7 \%$ protein, $0.6 \%$ lipid, $4.8 \%$ carbohydrate, $0.5 \%$ organic acid, $0.17 \mathrm{mg}$ carotin, $103 \mathrm{mg}$ vitamin C, $292 \mathrm{mg}$ vitamin A and some mineral elements [2, 3]. In recent times, pepper becomes a valuable commodity, because it is not only fresh food in meal but also makes a lot of products and raw materials for food processing industry. It can be used in alcohol type to resist hoarseness, treat emerods, flatulence and dysentery [3]. Cultivation of

Corresponding author: Hai Thi Hong Truong, Ph.D., research field: molecular plant breeding of horticulture science. pepper is high potential in Vietnam, because it is easy to plant, not choosy soil and suitable for many ecological areas. Pepper can harvest many times and is simple for treatment or process (dry, powder, pepper sauce). In addition, pepper powder is the first of exporting spice-vegetable commodities [4]. Within advantage characteristics, pepper overcomes market's risks, maintains stable prices and ensures producer's benefits. Pepper have been cultivated in Vietnam long time ago, but mainly in centre of Vietnam and suburban areas or densely populated areas of Southern and Northern parts.

In Thua Thien Hue, pepper is the most popular spicy vegetable and almost indispensable in every meals. Strengthening pepper's production is to utilize land efficiently, improve soil by alternate crops, intercropping and overlapping crops, and increase efficient economic. However, in Thua Thien Hue, 
pepper production area is decreased due to local variety having low level of resistance to disease, insect and high pollen contamination due to hot and humid weather. These caused local variety degraded and contaminated. To enhance value of pepper productions, selection of high yield and good qualities varieties are needed. The objective of this study was to evaluate induced pepper lines on growth ability, fruit qualities and yield to select promised lines for introducing into crop system and breeding programs in Thua Thien Hue.

\section{Materials and Methods}

\subsection{Materials}

A total of seven pepper accessions, including five introduced accessions-YT1, YT2, YT3, YT4, KR1 from National Institute of Horticultural and Herbal Science (NIHHS), Korea, and two local accessionsChia Voi and Moi were used in this study (Table 1).

\subsection{Methods}

The experiment was performed during summer-autumn season from May to October 2014 in a greenhouse of Hue University of Agricultural and Forestry. The experiment was laid out in random complete block design (RCBD) with three replications. Each plot contained eight plants with spacing of 80 $\mathrm{cm}$ between rows and $40 \mathrm{~cm}$ between plants. Density was 30,000 plants/ha.

The cultivated process based on documents of the national technical regulations on testing for value of cultivation and use of hot pepper and sweet pepper varieties of Ministry of Agriculture and Rural Development (QCVN01-64:2011/BNNPTNT) [5]. In nursery stage, seeds of each accession were sown in plastic trays comprising of $40 \%$ subsurface, $40 \%$ coconut fibre and $20 \%$ manure. Seedlings with $4-5$ true leaves were transplanted to open field experiment. Total of fertilizer applied for experiment field included 15 tons manure/ha, $110 \mathrm{~kg} \mathrm{~N} / \mathrm{ha}, 80 \mathrm{~kg}$ $\mathrm{P}_{2} \mathrm{O}_{5} /$ ha and $140 \mathrm{~kg} \mathrm{~K} \mathrm{O} / \mathrm{ha}$. The basal fertilizing contained $100 \%$ manure, $100 \%$ superphosphate, $1 / 3$ amount potassium and $1 / 3$ amount urea of total fertilizer were applied before transplanting. Fertilizers were supplied once a month after transplanting four weeks with potassium and urea. Watering to keep field humidity at $70 \%-75 \%$ was carried out regularly. Weeding and field hygiene were performed [6].

The experiment was evaluated for plant structure, morphological traits, growth traits, fruit's quantitative and qualitative characteristics, yield components and yield of seven pepper accessions. The evaluation was processed on 21 characteristics during the study. Data were collected from five plants per plot and analyzed by analysis of variance (one-way ANOVA) by Statistix 9.0 trial version. Differences between mean values were compared using Duncan's test at $P<0.05$ [7].

\section{Results and Discussion}

\subsection{Horticultural Characters}

\subsubsection{Plant Structure and Morphological Traits}

Plant structure and morphological traits are depending on genetics of variety to help distinguish differences among pepper varieties. Peeraullee and Rangoo-Sanmukhiya [8] emphasized that morphological characterization is an important target. Plant material collected for molecular analysis is based on difference of phenotype. There are three types of plant structure of pepper, such intermediate, erect and spread. According to Chaux and Foury [9], the plant habit is determined by the bifurcation of the main stem. Stem which is observed as intermediate (compact) type, divides many primary branches forming angle from $60^{\circ}$ to $90^{\circ}$. So, this plant habit is considered stable and prevents falling down from strong wind. Erect plant habit is easy to fall, because plant height is high and primary branches make angle less than $45^{\circ}$. According to result from Table 2, almost accessions had intermediate habit, except for Moi which was erect. Stem of indeterminate habit type has one or two flowers developed per node, and shortened internodes never develop. This result is in the in agreement with 
study of Zhani et al. [10].

The number of flower per node affects fruit number and actual yield. Only YT1 had one or two flowers per node, the remained pepper lines had one flower. This type is the typical flowering of the Capsicum species as one flower per axil located at each node and intersected by two branches [11]. Position of flower and fruit are related with specific of variety. Flower and fruit of Chia Voi was pendant, Moi was erect. Accessions YT1, YT2, YT3, YT4 and KR1 had pendant fruit. Normally, pendant fruit is bigger and longer than those which were erect.

Pepper flower is hermaphroditic and self-pollinated. However, high cross pollination ratio still occurs, because stigma is higher than anther in some accessions. Stigma of YT1, YT3 and Moi was higher than anther. Stigma of the remained accessions was the same position with anther.

Stem, leaf and node of pepper accessions were differed in color. Light green, green and dark green were observed in stem color, green and dark green were in leaf and light or dark violet were in node. Color of stem, leaf and node of accession Moi was same with those in YT2; YT4 and Chia Voi had the same color of stem and leaf. Both YT3 and KR1 had green stem and light violet node, but different leaf color (Table 2).

These results showed that accession YT4 had almost characteristics like Chia Voi. YT1 accession had a lot morphological traits alike Moi.

\subsubsection{Growth Traits}

Growth traits indicate adaptability of weather condition of the accessions. The results were recorded in Table 3. Number of leaves per plant not only depends on variety, but also expresses growth ability. Numbers of leave of the accessions were observed significantly different. It ranged from 8.16 to 13.11 leaves. Moi had the highest of leaves (13.11 leaves), whereas YT2 was the lowest (8.16 leaves). Accession YT4 had the highest number of leaves among introduced accessions, followed by YT1 (8.84 leaves).

Plant height is one of specificity of variety and related to plant structure. The results in Table 3 showed that Moi had erect plant structure and the highest plant height $(99.72 \mathrm{~cm})$ and significantly different from the other accessions obtained as intermediate structure. The highest plant of introduced accessions was found in KR1 $(69.45 \mathrm{~cm})$, follow by YT4 $(62.21 \mathrm{~cm})$ and YT2 $(51.06 \mathrm{~cm})$. YT3 had the lowest plant height $(40.92 \mathrm{~cm})$ and next was Chia Voi

Table 1 List of pepper accessions used.

\begin{tabular}{|c|c|c|}
\hline Number & Accession name & Place of collection \\
\hline \multicolumn{3}{|c|}{ Introduced accessions } \\
\hline 1 & YT1 & NIHHS \\
\hline 2 & YT2 & NIHHS \\
\hline 3 & YT3 & NIHHS \\
\hline 4 & YT4 & NIHHS \\
\hline 5 & KR1 & NIHHS \\
\hline \multicolumn{3}{|c|}{ Local accessions } \\
\hline 6 & Chia Voi & Thua Thien Hue \\
\hline 7 & Moi & Thua Thien Hue \\
\hline
\end{tabular}

Table 2 Plant structure and morphological traits of pepper accessions.

\begin{tabular}{|c|c|c|c|c|c|c|c|c|c|}
\hline \multirow{2}{*}{$\begin{array}{l}\text { Target } \\
\text { accession }\end{array}$} & \multirow[b]{2}{*}{ Plant habit } & \multicolumn{3}{|c|}{ Characteristics of flower } & \multirow{2}{*}{$\begin{array}{l}\text { Fruit } \\
\text { position }\end{array}$} & \multicolumn{4}{|c|}{ Color } \\
\hline & & $\begin{array}{l}\text { Number of flower } \\
\text { per node }\end{array}$ & Position & $\begin{array}{l}\text { Position of stigma } \\
\text { compares with anther }\end{array}$ & & Flower & Stem & Leaf & Node \\
\hline YT1 & IM & 1 or 2 & IM & Higher & $\mathrm{P}$ & W & DG & DG & DV \\
\hline YT2 & IM & 1 & IM & Same & $\mathrm{P}$ & $\mathrm{W}$ & DG & DG & LV \\
\hline YT3 & IM & 1 & IM & Higher & $\mathrm{P}$ & W & G & DG & LV \\
\hline YT4 & IM & 1 & IM & Same & $\mathrm{P}$ & $\mathrm{W}$ & LG & G & - \\
\hline KR1 & IM & 1 & IM & Same & $\mathrm{P}$ & $\mathrm{W}$ & G & G & LV \\
\hline Chia Voi & IM & 1 & $\mathrm{P}$ & Same & $\mathrm{P}$ & W & LG & G & - \\
\hline Moi & $\mathrm{E}$ & 1 & $\mathrm{E}$ & Higher & $\mathrm{E}$ & W & DG & DG & LV \\
\hline
\end{tabular}


Table 3 Growth traits of pepper accessions used in the study.

\begin{tabular}{llll}
\hline Accession & Number of leaves per plant & Plant height $(\mathrm{cm})$ & Number of branches \\
\hline YT1 & $8.84^{\mathrm{de}}$ & $47.32^{\mathrm{bc}}$ & $22.12^{\mathrm{a}}$ \\
YT2 & $8.16^{\mathrm{e}}$ & $51.06^{\mathrm{bc}}$ & $32.11^{\mathrm{a}}$ \\
YT3 & $8.64^{\mathrm{de}}$ & $40.92^{\mathrm{c}}$ & $19.31^{\mathrm{a}}$ \\
YT4 & $9.54^{\mathrm{d}}$ & $62.21^{\mathrm{bc}}$ & $31.37^{\mathrm{a}}$ \\
KR1 & $8.67^{\mathrm{de}}$ & $69.45^{\mathrm{b}}$ & $33.89^{\mathrm{a}}$ \\
Chia Voi & $11.50^{\mathrm{c}}$ & $43.72^{\mathrm{c}}$ & $23.33^{\mathrm{a}}$ \\
Moi & $13.11^{\mathrm{b}}$ & $99.72^{\mathrm{a}}$ & $33.67^{\mathrm{a}}$ \\
\hline LSD $_{0.05}$ & 0.92 & 22.26 & 19.44 \\
\hline
\end{tabular}

${ }^{\mathrm{a}-\mathrm{e}}$ Mean different letters in a column indicate significantly difference (Duncan's test, $P<0.05$ ).

$(43.72 \mathrm{~cm})$. The plant height of pepper in this study is similar results of Occhiuto et al. [12], Misra et al. [13] and Prasath et al. [14].

In pepper, more branches will give more flowers, because flower appears at where branch sprouts. Total of branches were different between accessions, ranging from 19.31 to 33.89 , but there were no significant difference. The highest number of branches was found in KR1 (33.89 branches) and the lowest was YT3 (19.31 branches). Accession Moi, YT2 and YT4 obtained over 30 branches per plant. The result is in agreement with result of Misra et al. [13] that total of branches of pepper, which included primary, secondary and tertiary branches, ranged from 18 branches to 28 branches. Accessions YT4, KR1 and YT2 showed good adaptability under Thua Thien Hue weather conditions.

\subsection{Fruit Quality Traits}

Fruit traits are essential for pepper fruits used in the industry or cooking, either in natural or as paprika, or paste or dehydrated pepper or in conserves [15]. Characterization of fruit, such as shape, size, color, pungency and flavor, is used to classify chili varieties [16, 17]. The quality parameters including fruit length, diameter, wall thickness and fruit color are presented in Table 4. Fruit size was recorded by length and diameter. Fruit length ranged from $3.82 \mathrm{~cm}$ to $9.09 \mathrm{~cm}$. Chia Voi had the longest fruit $(9.09 \mathrm{~cm})$, whereas Moi had the shortest one $(3.82 \mathrm{~cm})$. KR1 and YT2 had long fruit with $8.29 \mathrm{~cm}$ and $7.34 \mathrm{~cm}$, respectively. Fruit diameter of Moi was the smallest and significant difference from other accessions. Fruit diameter of YT2 was found to be the widest $(2.03 \mathrm{~cm})$, next was Chia Voi $(1.99 \mathrm{~cm})$ and KR1 $(1.89 \mathrm{~cm})$. All of accessions gave ratio of length and diameter greater than 1. The fruit quality trait in this study is in agreement with those in studies of Misra et al. [13], Patel et al. [18], Akinci, S. and Akinci, I. E. [19]. Winch [20] found difference in the thickness of the pericarp related to the ability of the genotype in the partition of assimilation. Fruit wall thickness is one of genetic characteristics and rangs from $0.86 \mathrm{~mm}$ to 2.24 mm. YT4, KR1 and Chia Voi had the thickest fruit wall (from $2.22 \mathrm{~mm}$ to $2.24 \mathrm{~mm}$ ) and Moi had the thinnest wall $(0.86 \mathrm{~mm})$, which were significantly different from other accessions. Montesano et al. [21] reported that their Capsicum annuum germplasm was obtained with fruit length 4.00-16.67 cm, fruit width 2.7-4.92 cm and fruit wall thickness 2.00-4.00 mm [12], while Occhiuto et al. [12] reported that their three clusters of pepper germplasm were found average fruit length in 4.34, 6.91 and $13.95 \mathrm{~cm}$, average width in 6.21, 3.64 and $1.71 \mathrm{~cm}$ and average wall thickness in 3.6, 0.9 and $1.9 \mathrm{~mm}$, respectively. The results from Table 4 showed that Chia Voi had light green fruits and Moi had dark green fruits at immature stage, whereas the other accessions had green fruits. Mature pepper fruit is produced for culinary applications and the color is an important determinant of quality of fresh and processed product. Dark red is better for powder processing. Fruit of almost accessions had dark red color at mature stage, except for KR1 and Chia Voi. The typical red color of fruit at mature stage is related 
Table 4 Fruit characteristics of pepper accessions used in the study.

\begin{tabular}{llllll}
\hline \multirow{2}{*}{ Accession } & Fruit length $(\mathrm{cm})$ & Fruit diameter $(\mathrm{cm})$ & Fruit wall thickness $(\mathrm{mm})$ & \multicolumn{2}{c}{ Fruit color } \\
\cline { 4 - 6 } & & & $1.99^{\mathrm{ab}}$ & $\mathrm{G}$ & Mature \\
YT1 & $5.93^{\mathrm{d}}$ & $1.65^{\mathrm{a}}$ & $2.12^{\mathrm{ab}}$ & $\mathrm{G}$ & $\mathrm{DR}$ \\
YT2 & $7.34^{\mathrm{bc}}$ & $2.03^{\mathrm{a}}$ & $1.85^{\mathrm{b}}$ & $\mathrm{G}$ & $\mathrm{DR}$ \\
YT3 & $6.38^{\mathrm{cd}}$ & $1.65^{\mathrm{a}}$ & $2.24^{\mathrm{a}}$ & $\mathrm{G}$ & $\mathrm{DR}$ \\
YT4 & $6.26^{\mathrm{cd}}$ & $1.74^{\mathrm{a}}$ & $\mathrm{G}$ & $\mathrm{R}$ \\
KR1 & $8.29^{\mathrm{ab}}$ & $1.89^{\mathrm{a}}$ & $2.24^{\mathrm{a}}$ & $\mathrm{LG}$ & $\mathrm{R}$ \\
Chia Voi & $9.09^{\mathrm{a}}$ & $1.99^{\mathrm{a}}$ & $2.22^{\mathrm{a}}$ & $\mathrm{DG}$ & $\mathrm{DR}$ \\
Moi & $3.82^{\mathrm{e}}$ & $0.77^{\mathrm{b}}$ & $0.86^{\mathrm{c}}$ & & \\
\hline LSD $_{0.05}$ & 1.33 & 0.53 & 0.37 &
\end{tabular}

${ }^{\mathrm{a}-\mathrm{e}}$ Mean different letters in each columns indicate significantly difference (Duncan's test, $P<0.05$ ).

$\mathrm{R}=$ red, $\mathrm{DR}=$ dark red, $\mathrm{LG}=$ light green, $\mathrm{DG}=$ dark green.

Table 5 Yield and yield components.

\begin{tabular}{llllll}
\hline Accession & $\begin{array}{l}\text { Percentage of } \\
\text { fruit setting }(\%)\end{array}$ & $\begin{array}{l}\text { Fruit weight } \\
(\mathrm{g})\end{array}$ & $\begin{array}{l}\text { Number of fruits } \\
\text { per plant }\end{array}$ & $\begin{array}{l}\text { Predicted yield } \\
(\mathrm{kg} / \mathrm{ha})\end{array}$ & $\begin{array}{l}\text { Actual yield } \\
(\mathrm{kg} / \mathrm{ha})\end{array}$ \\
\hline YT1 & $4.83^{\mathrm{c}}$ & $5.94^{\mathrm{b}}$ & $3.17^{\mathrm{c}}$ & $583.44^{\mathrm{bc}}$ & $386.45^{\mathrm{bc}}$ \\
YT2 & $21.10^{\mathrm{ab}}$ & $8.08^{\mathrm{a}}$ & $12.18^{\mathrm{ab}}$ & $2,966.00^{\mathrm{a}}$ & $892.30^{\mathrm{ab}}$ \\
YT3 & $12.83^{\mathrm{bc}}$ & $6.03^{\mathrm{b}}$ & $3.31^{\mathrm{c}}$ & $602.91^{\mathrm{bc}}$ & $490.450^{\mathrm{bc}}$ \\
YT4 & $14.81^{\mathrm{abc}}$ & $7.00^{\mathrm{ab}}$ & $5.63^{\mathrm{bc}}$ & $1,210.10^{\mathrm{bc}}$ & $958.80^{\mathrm{ab}}$ \\
KR1 & $24.56^{\mathrm{ac}}$ & $7.25^{\mathrm{ab}}$ & $15.78^{\mathrm{a}}$ & $3,433.90^{\mathrm{a}}$ & $1,397.80^{\mathrm{a}}$ \\
Chia Voi & $22.72^{\mathrm{ab}}$ & $7.40^{\mathrm{ab}}$ & $7.69^{\mathrm{bc}}$ & $1,559.90^{\mathrm{b}}$ & $979.85^{\mathrm{ab}}$ \\
Moi & $6.74^{\mathrm{c}}$ & $1.35^{\mathrm{c}}$ & $4.50^{\mathrm{c}}$ & $96.77^{\mathrm{d}}$ & $79.85^{\mathrm{c}}$ \\
\hline LSD $_{0.05}$ & 10.89 & 1.46 & 6.61 & $1,316.50$ & 685.300 \\
\hline
\end{tabular}

${ }^{\mathrm{a}-\mathrm{d}}$ Mean different letters in each columns indicate significantly difference (Duncan's test, $P<0.05$ ).

to transformation of chloroplasts into chromoplasts [22].

According to these results, KR1, YT2 and Chia Voi had big fruit and YT4 had the thickest fruit wall.

\subsection{Yield and Yield Components}

The results in Table 5 showed that percentage of fruit setting ranged from $4.83 \%$ to $24.56 \%$. KR1 had the highest rate $24.56 \%$, whereas YT1 had the lowest rate $4.83 \%$, followed by Moi 6.74\%. These accessions were significant difference from other accessions. The largest fruit was observed in YT2 (8.08 g), followed by Chia Voi (7.40 g) and KR1 (7.25 g), whereas Moi contained the smallest fruit (1.35 g). The difference was highly significant among accessions. The result was similar to fruit weight (from $2.17 \mathrm{~g}$ to $19.84 \mathrm{~g}$ ) reported by Prasath et al. [14] and average fruit weight was $8.37 \mathrm{~g}$. The results showed fruit weight was increased due to increase of its width. Silva et al. [23] also reported that the accessions which showed greater fruit average also presented larger fruit diameter average. In addition, fruit wall thickness and fruit weight were positive correlated, which was reported by Lannes et al. [24]. Somashekhar and Salimath [25] and Schuelter et al. [26] described that the fruit weight was related inversely to fruit number per plant. Yield is one of important traits reflecting results and influenced by applied techniques during planting and caring process. Chili pepper may yield up to 18 tons/ha and sweet pepper up to 30 tons/ha in open fields [27]. There were significant differences among accessions in all of yield components and yield. Predicted yield ranged from $96.77 \mathrm{~kg} / \mathrm{ha}$ to $3,433.90$ $\mathrm{kg} / \mathrm{ha}$. KR1 had the highest predicted yield (3,433.90 kg/ha), next was YT2 (2,966 kg/ha), whereas Moi had the lowest predicted yield (96.77 kg/ha). The difference was highly significant among accessions.

Accession KR1 was obtained with the highest 
actual yield (1,397.80 kg/ha), next was Chia Voi (979.85 kg/ha) and YT4 (958.80 kg/ha). Moi had the lowest yield (79.85 kg/ha). However, there was no significant difference among these accessions.

\section{Conclusions}

All of accessions can grow under Thua Thien Hue condition. Almost accessions had intermediate plant structure, which is easy to take care and avoid strong wind or storm. The anther was observed to be lower than stigma in YT1, YT3 and Moi, which caused high pollen contaminated ability. Fruits of control Moi were erect and small. KR1 had higher yield in comparison with control Chia Voi. Yield of YT2 and YT4 was equivalent to local variety Chia Voi. Besides, Chia Voi and Moi (local varieties), KR1, YT2 and YT4 showed good adaptability under Thua Thien Hue conditions based on horticultural traits. These lines were obtained with high yield and good quality. Therefore, these lines should be introduced to crop system and breeding programs in Thua Thien Hue.

\section{References}

[1] Splittstoesser, W. E. 1984. "Growing Individual Vegetables: Peppers.” In Vegetable Growing Handbook. Connecticut, USA: AVI Publishing Company, Inc., 251-2.

[2] Ha, T. V., and Tran, B. Q. 2004. Preserving Fresh Vegetables and Sell Products. Hanoi: Agriculture Publisher. (in Vietnamese)

[3] Mai, A. T. P. 1999. Techniques on Planting of Important Vegetable. Hanoi: Agriculture Publication, 15-30. (in Vietnamese)

[4] Tran, T. K., and Nguyen, H. C. 2005. Techniques on Safe, Clean Vegetables and Processing, Exporting. Thanh Hoa: Thanh Hoa Publisher. (in Vietnamese)

[5] Ministry of Agriculture and Rural Development. 2011. Circular No. QCVN 01-64:2011/BNNPTNT of National Technical Regulations on Testing for Value of Cultivation and Use of Hot Pepper and Sweet Pepper Varieties. (in Vietnamese)

[6] Ministry of Agriculture and Rural Development (MARD). 2011. Circular No. 48/2011/TT-BNNPTNT of National Technical Regulation on Testing Crop Varieties. (in Vietnamese)

[7] Duncan, E. B. 1995. "Multiple Range Test and Multiple
F-Tests.” Biometrics 11 (1): 1-42.

[8] Peeraullee, N., and Ranghoo-Sanmukhiya, V. M. 2013. "Assessment of Genetic Diversity in Local Chilli (Capsicum annuum) Varieties in Mauritius.” Int. J. Agric. Biol. 15 (5): 891-6.

[9] Chaux, C. I., and Foury, C. I. 1994. "Peppers.” In Vegetables Fruit-Vegetable Productions. Paris: Lavoisier.

[10] Zhani, K., Hamdi, W., Sedraoui, S., Fendri, R., Lajimi, O., and Hannachi, C. 2015. "A Comparative Study of Morphological Characterization of Tunisian Accessions of Chili Pepper (Capsicum frutescens L.).” International Research Journal of Engineering and Technology 2 (4): 87-94.

[11] Erard, P., Bellamy, A., Berry, D., Buffière, A., Capy, A., Dumolin, J., Guillon, A., Hutin, C., and Izard, D. 2002. Pepper. Paris: CTIFL Publisher. (in France)

[12] Occhiuto, P. N., Peralta, I. E., Asprelli, P. D., and Galmarini, C. R. 2014. "Characterization of Capsicum Germplasm Collected in Northwestern Argentina Based on Morphological and Quality Traits.” Agriscientia 31 (2): 63-73.

[13] Misra, S., Lal, R. K., Darokar, M. P., and Khanuja, S. P. S. 2011. "Genetic Variability in Germplasm Accessions of Capsicum annuum L..” American Journal of Plant Sciences 2: 629-35.

[14] Prasath, D., Ponnuswami, V., and Muralidharan, V. 2007. "Evaluation of Chilli (Capsicum spp.) Germplasm for Extractable Colour and Pungency.” Indian J. Genet. 67 (1): 97-8.

[15] Pinto, C. M. F., Caliman, F. R. B., Moreira, G. R., Mattos, R. N., Rocha, P. R. R., Venzon, M., and Paula, J. T. J. 2007. "Pimenta (Capsicum spp.)." In 101 Cultures: Agricultural Techniques Book, edited by Paula, J. T. J., and Venzon, M. Belo Horizonte: EPAMIG, 625-32.

[16] Bosland, P. W. 1992. “Chiles: A Diverse Crop.” Hort. Technol. 2 (1): 6-10.

[17] Bosland, P. W. 1994. "Chillies: History, Cultivation and Uses.” In Species, Herbs and Edible Fungi, edited by Charambous, G. New York: Elsevier Publication, 347-66.

[18] Patel, J. A., Shukla, M. R., Doshi, K. M., Patel, B. R., and Patel, S. A. 1998. "Combining Ability Analysis for Green Fruit Yield and Yield Components in Chilli (Capsicum annuum L.)." Capsicum and Eggplant Newsletter 17: 34-7.

[19] Akinci, S., and Akinci, I. E. 2004. "Evaluation of Red pepper for Spice (Capsicum annuum L.) Germplasm Resource of Kahramanmaras Region (Turkey).” Pakistan Journal of Biological Science 7 (5): 703-10.

[20] Winch, T. 2006. Growing Food: A Guide to Food Production. Hereford, UK: Springer.

[21] Montesano, V., Negro, D., Bitonte, D., Montemurro, F., 
De Lisi, A., and Sarli, G. 2014. "Characterization of a Capsicum annuum L. of a Germplasm Collection.” International Journal of Agri. Science 4 (12): 499-508.

[22] Hornero-Méndez, D., and Minguez-Mosquera, M. I. 2000. “Xanthophyll Esterification Accompanying Carotenoid Overaccumulation in Chromoplast of Capsicum annuum Ripening Fruits Is a Constitutive Process and Useful for Ripeness Index.” J. Agric. Food Chem. 48 (5): 1617-22.

[23] Silva, A. R., Nascimento, M., Cecon, P. R., Sapucay, M. J. L. C., Rêgo, E. R., and Barbosa, L. A. 2013. "Path Analysis in Multicollinearity for Fruit Traits of Pepper.” IDESIA (Chile) 31 (2): 55-60.

[24] Lannes, S. D., Finger, F. L., Schuelter, A. R., and Casali, V. W. D. 2007. "Growth and Quality of Brazilian
Accessions of Capsicum chinense Fruits.” Scientia Horticulturae 112 (3): 266-70.

[25] Somashekhar, S. A. P., and Salimath, P. M. 2008. "Estimation of Gene Effects for Fruit Yield and Its Components in Chilli (Capsicum annuum L.)." Karnataka Journal Agricultural Sciences 21: 181-3.

[26] Schuelter, A. R., Pereira, G. M., Amaral, A. T., and Casali, V. W. D. 2010. "Genetic Control of Agronomically Important Traits of Pepper Fruit Analyzed by Hayman's Partial Diallel Cross Scheme.” Genetics Molecular Research 9 (1): 113-7.

[27] Grubben, G. J. H., and El-Tahir, I. M. 2004. "Capsicum annuum L..” In Plant Resources of Tropical Africa, edited by Grubben, G. J. H., and Denton, O. A. Wageningen, Netherlands: Backhuys Publishers, 154-63. 